\title{
HUMAN RESOURCES MANAGEMENT AND LECTURER'S JOB SATISFACTION IN TETIARY INSTITUTIONS IN AKWA IBOM AND CROSS RIVER STATES
}

COMFORT R. ETOR

(Received 1, September 2014; Revision Accepted 4, September 2014)

\begin{abstract}
The study examines the extent to which the management of human resources by the administrators influence lecturers' job satisfaction in tertiary institutions in Akwa Ibom and Cross River States, Nigeria. The ex-post-facto research design was used for the study. The population of the study was 2286 lecturers from nine (9) tertiary institutions from the two states out of which 600 lecturers were randomly sampled from six (6) tertiary institutions in the two states. The statistical analysis used to test the only one hypothesis in the study was one-way analysis of variance (ANOVA), at .05 alpha level of significance. The study revealed that administrators' human resources management effectiveness has a significant influence on lecturers' job satisfaction with respect to workload, professional status, opportunity for academic publication and administrators' staff relationship. It was therefore recommended among other things that administrators of tertiary institution should ensure that the number of lecturers employed meet the required student-teacher ratio by the National Universities Commission (NUC) for improved performance and job satisfaction.
\end{abstract}

\section{INTRODUCTION}

Every administrator has the great task of managing the staff in order to achieve the goals of the organization. This is because human resources play a prominent role in the management of other resources, such as materials, equipment and tools as well as money entrusted into their care. Uche,(2011) maintained that human resource refers to organization employees, which are described with reference to their training, experience, judgment, intelligence, relationship and insight. In the words of Adetoro (2009) and Akpan (2001), human resource is of great importance to any organization or nation because it constitutes a usable commodity as well as decides how much can be achieved with other resources. In the same vein, Onwuka (1988) saw human resource as the most important resource because it is saddled with the onerous task of coordinating other available resources for the attainment of the goals of the organization. Human resource management according to Peretomode (1995) is that functions of all organizations which makes for effective utilization of human resources to achieve not only the objectives of the organization but also the satisfaction and development of employees. He went on to define human resource management in education as the harnessing of the totality of workers' skills, knowledge, energies, talents latent capabilities, social characteristics such as belief, to achieve the objectives of education and at the same time make the workers to be part and parcel of the organization in fulfilling their life goals.

As implied in the definition, the importance of human resource management can not be over emphasized. Peretomode (1995) stated the importance of human resource management to include: Identifying the current and future human resources requirements so that there will be no shortage of human resources to work towards the realization of the organizational

Comfort R. Etor, Department of Educational Administration and Planning, University of Calabar, Calabar, Cross River State, Nigeria. 
goals, Ensuring that the staff regularly undergoes development programmes to enable them carryout their present and future duties properly, providing grading and evaluation system of staff which enables the employee and the employer to know how far the employee has fared during a specific period, Rewarding good performance to motivate employees and disciplines staff for poor performance as a corrective measure.

From the forgoing, human resource management makes for constant supply of personnel for the organization. The policies and objectives of the organization are communicated to the employees and this knowledge boosts their moral. The development programmes provided for staff make them very functional in the organization. The grading and evaluation make for easy assessment of staff, while the reward for good performance motivates employee for higher productivity. Well managed human resources is very likely to have job satisfaction in any organization.

Many activities are involved in human resources management but the major ones as enumerated by Armstrong (2009), Schermerhorn, Hunt and Osborn (1998), Idih (1997) Peretomode (1995), Onuka (2009) and Emechebe (2009) include human resource planning, recruitment and selection, induction and orientation, knowledge management, development programmes, health, employee safety, performance appraisal, promotion, retirement, as well as industrial relations. Some of these are roles of the head of department.

Human resources planning as defined by Ofojebe (2009) is a process which attempts to provide adequate human resource to achieve future organization objectives. In the same vein Peretomode (1995), maintained that it is through the human resource planning process that an organization ensures that it has the right number of people, with the right skills, in the right places and at the right time and that the objectives of the school will be achieved because these people are capable of carrying out these tasks effectively. He confirmed that the administrators must know the requirements of the school in terms of types of skills, levels and age category, present number available and then forecasting future needs in areas of changes. Ojojebe (2009) confirmed that it involves forecasting of future needs of employees of various types and setting out conditions for continuous development of the employees with this process, the people that have the required skills for the work are employed. Consequently when the numbers of teachers are in proportion with number of students, job satisfaction becomes possible, especially if they are properly utilized by the administrators.

FGN (2008) stated the major functions of higher education to include the development of new knowledge through research, the training of very high level personnel through teaching, and the provision of services to the society. The implication of the above is that the teachers or lecturers recruited and selected to teach in these institutions must be very sound academics. The recruitment and selection of lecturers should normally be rooted through the department where the heads of departments will attest to the fact that the applicant have sound intellectual ability and can cope with the task of research, teaching and community service with less difficulty. In the words of Nnachi (2009: 193), employment of teachers into tertiary institution should involve rigorous examinations, interview and screening to give quality to the sector after which those qualified should be sent for training to acquire teaching experience, ethics, norms, regulations and values. This means that the institutional administrators should not independently employ and impose employees on heads of departments. In this regard, Agwokoagbuo (2003), pointed out that the candidates with strong personality behind them are generally selected for appointment. This has often resulted in the competent and incompetent working in the system. Besides, the incompetent personnel would surely breed poor results and undesirable attitudes in students towards education. It is even easier to manage a competent staff in that, if the necessary working conditions are put in place such as adequate facilities, instructional materials, motivation etc, such a worker may be satisfied with his or her job, but an incompetent lecturer what can be done to satisfy him or her in the job? Absolutely nothing. Therefore if the departmental heads must manage the teachers effectively and efficiently they must have a hand in the recruitment and selection process.

Owing to the dynamic nature of our society our educational system must be dynamic to remain functional. The skills and knowledge acquired yesterday may not be very useful today, hence the need for training of teachers through 
various development programmes. Peretomode (1995) maintained that developmental programmes are designed to increase the knowledge, skills, experience, attitude as well as release employee's latent potential so as to meet the present and future job requirements and thus achieve the institutional objectives. Graham (1979) stressed that a development programme has the import of dual function of utilization and motivation. Development programme allows better use to be made of human resources by improving employees' ability to perform the task required by the institution by giving employees a feeling of master over their work and recognition by management, and that would promote their job satisfaction.

Every lecturer in the institution of higher learning as pointed out by Bland (1990) has a high degree of personnel responsibility for assembling and presenting the course content to achieve instructional objectives and therefore the management should give every positive encouragement to the lecturer by recommending him or her for development programme or training such as workshop, conference, seminars, in-service programme for Master, Ph.D or post doctorate, depending on his academic status. Asiabaka (2009) and Odoegbuaem (2003) also believed that workshops, seminars, team meeting, exchange programme, supervision and enforcing discipline can enhance human resources management practices. In a study by Dilworth and Baker (1991) one of the findings highlighted the importance of advancement and training opportunities in promoting job satisfaction of teachers especially those in higher institutions. In another study Idih (1997) outlined the importance of developmental programme to include greater productivity, qualitative performance, adaptability to new methods, lower labour turnover, less acquisition of qualification for greater responsibilities and status, keeping in touch with counterparts and new development within and outside the country in professional growth. The heads of departments should not practice favoritism when opportunity for training arises. As pointed out by Aguokogbuo (2003) recommendation for training should be done on merit.

The effective head of department should be able to appraise the teachers performance adequately. Performance appraisal is the process of assessing the degree of the employees effectiveness in carrying out his assigned duties in order to achieve the goals of the institutions. Schermerhorn Hunt and Osborn (1998) summited that performance appraisal is the process of evaluating performance and providing feed back for making of performance adjustment. Denga (1999) stated that the administrator should use assessment productivity instrument that will reflect items such as commitment level to work, attitude to work, rate, extra performance and unusual initiative amongst others.

The head, in appraising lecturers, should ensure that there is no favoritism and victimization. He should be fair and objective. This can also make a committed lecturer happy and self actualized in the job. Based on this, the strength and weakness of the staff can be identified easily and remedied through recommendation for development programmes as the need arises.

Lecturers' job satisfaction in terms of work load, professional status, opportunities for academic publication and administrators - staff relations are discussed below. There is need for organizations to ensure that workers have job satisfaction. The term satisfaction, may be defined as a condition in life, activity or an event at which the person involved feels fulfilled and enjoys his continuous involvement in that activity or event. Robbins (1994) maintained that to enhance job satisfaction of lecturers, the administrators should not give them too challenging a work assignment because it creates frustration and feeling of failure, but under conditions of moderate challenge most employees will experience pleasure and satisfaction. Lecturers' job satisfaction with work load is very important. Any worker that is over loaded with work will not be happy, neither will the worker that is under utilized be satisfied. It is the place of the head to assign duties to lecturers based on their specialization and capability. Nsa and Isaac (2007) pointed out that where the number of staff are not sufficient, the available staff are always over loaded, and this often leads to poor productivity, Zwalchir (2009) believed it leads to stress. Therefore the head of department should be careful in assigning duties to lecturers to avoid undesirable consequences.

$$
\text { Lecturers' job satisfaction with }
$$

professional status is the ladder to all achievement in the system. The lecturer has the 
uphill task of forming course outline, teaching, examining, marking, researching, attending conferences and so on. These are the duties that make him self actualized. The administrators should help lecturers to achieve their professional status and growth by recommending them for staff development programmes in and outside the university. Mgbekem (2004) maintained that these programmes improve productivity and enhance professional development. This is true, especially when lecturers are upgraded and or promoted after such programmes.

Lecturers satisfaction with academic publication is of great concern to lecturers in all tertiary institutions in Nigeria. Lecturers are expected to research, write and publish articles in journals in and outside the country before they are promoted from junior level to the zenith. Mgbekem (2004) confirmed that if lecturers fail to comply with these directives from the management of their institutions, they will stagnate on their first position of employment. This can be very frustrating to anyone. The administrators can help reduce frustration and engender job satisfaction by reducing workload of lecturers, publishing information for conferences and workshops on time as well as helping them to have access to journal of repute for easy publication of their articles.

Lecturers' satisfaction with administrators - staff relations is of great importance in any department. Where there is a harmonious relationship between the administrators and staff, the work environment may change positively. Adetoro (2009) and Ibiam (2011) believed that the administrators who communicate, motivate, interact and supervise staff may encourage job satisfaction among them. Mgbekem (2004), Udo and Akpa (2010) confirmed that employees will work enthusiastically to achieve goals if they are treated well by the head.

\section{Statement of the problem}

Human resource has and will always remain the most important resources in any organization because it is saddled with the responsibility of manipulating and using other resources like money and materials for the purpose of achieving the goals of the organization. In most tertiary institutions in the two states, human resource with the right skills are not adequate. It is also often noticed that the number of students are by far more than the number of teachers in most of the schools and this may often results in low academic achievement among students and job dissatisfaction among the lecturers. More often than not, recruitment and selection of lecturers are done independently with the department, hence the incompetent flooding the system and causing problems for the minority competent who are always overworked. The problem of this paper put in question form is: does effective human resource management influence the job satisfaction of lecturers in tertiary institutions.

\section{Methodology}

The study area was Cross River and Akwa Ibom States. The research design used for the study was ex-post-facto. The population was all the lecturers in tertiary institutions in the two states. The available records in these nine tertiary institutions indicate that they were two thousand two hundred and eight six (2286) lecturers. The sample size for this study was 600 lecturers randomly sampled from six (6) tertiary institutions. Two hundred (200) lecturers were selected from twenty (20) departments in the universities of Calabar and Uyo respectively. Sixty (60) lecturers were selected from two (2) departments in College of Education (Akamkpa campus). In the same vein, sixty (60) lecturers were selected from ten (10) departments in the Federal College of Education Obudu. At the polytechnic, Ikot Osurua, Ikot Ekpenme forty (40) lecturers were sampled from ten (10) departments: forty (40) lecturers were also sampled from ten (10) department at the College of Education Afaha Nist, Nsit Ibom. This procedure was adopted in order to have a good representation of the staff strength from these institutions. In this regard six hundred copies of the questionnaire were administered, but five hundred and fifty-two (552) copies were retrieved $(92 \%)$ with a mortality rate of forty eight $(48 \%)$ of the entire sample size.

Data collection was carried out with the aid of research instrument titled 'Administration Resources management Effectiveness and Lecturers' Job satisfaction Questionnaire" (AREMELEJOSQ) on a four-point Likeret type scale. The respondents in the sample were categorized into three groups based on their scores on the scale of the research instrument that was designed to measure the administrators' material resources management effectiveness. 
The groups were formed based on the following criteria: Those that were above the mean score were categorized as high, those that were within the mean score were categorized as average, while those below the mean score were categorized as low. The statistical analysis used to test this hypothesis was the one way analysis of variance (ANOVA) at .05 alpha level of significance.

\section{Hypothesis}

There is no significant influence of administrators management of human resource and lecturers job satisfaction in terms of work load, professional status, opportunity of academic publication, administrators staff relations and overall job satisfaction. The result of the analysis are presented on table one.

Table One: Group means and standard deviations of lecturers' job satisfaction based on their perception of administrators' human resources management effectiveness

\begin{tabular}{lllll}
\hline Sub-variable & Group & N & Mean & SD \\
\hline Satisfaction with & 1(low) & 184 & 15.82 & 1.68 \\
Workload & 2(Average) & 189 & 16.54 & 1.62 \\
& 3 (High) & 179 & 16.85 & 1.73 \\
Satisfaction with & Total & $\mathbf{5 5 2}$ & $\mathbf{1 6 . 4 0}$ & $\mathbf{1 . 7 3}$ \\
Professional status & 1(low) & 184 & 16.11 & 1.81 \\
& & & & \\
& 2(Average) & 189 & 16.61 & 1.49 \\
Satisfaction with Opportunity & 3 (High) & 179 & 17.38 & 1.64 \\
for Academic publication & Total & $\mathbf{5 5 2}$ & $\mathbf{1 6 . 6 9}$ & $\mathbf{1 . 7 3}$ \\
& 1(low) & 184 & 16.05 & 1.67 \\
& & & & \\
Satisfaction with & 2(Average) & 189 & 16.92 & 1.61 \\
Administrators Staff Relations & 3 (High) & 179 & 17.04 & 1.68 \\
& Total & $\mathbf{5 5 2}$ & $\mathbf{1 6 . 6 7}$ & $\mathbf{1 . 7 1}$ \\
& 1(low) & 184 & 16.51 & 1.85 \\
& & & & \\
& 2(Average) & 189 & 17.24 & 1.78 \\
Overall lecturers Job satisfaction & 1(low) & 184 & 64.49 & 4.56 \\
& 2(Average) & 189 & 67.32 & 4.43 \\
& 3 (High) & 179 & 68.87 & 4.65 \\
& Total & $\mathbf{5 5 2}$ & $\mathbf{6 6 . 8 8}$ & $\mathbf{4 . 8 8}$ \\
\hline
\end{tabular}

Table Two: Results of analysis of variance of the influence of administrators' human resource management effectiveness on lecturers' job satisfaction

\begin{tabular}{|c|c|c|c|c|c|}
\hline Sub-variable & $\begin{array}{l}\text { Sources of } \\
\text { Variation }\end{array}$ & Sum of squares & df & Mean & f-Value \\
\hline \multirow[t]{3}{*}{ Satisfaction with Workload } & Between groups & 102.739 & 2 & 51.369 & $8.311^{*}$ \\
\hline & Within groups & 1540.173 & 549 & 2.805 & \\
\hline & Total & 1642.911 & 551 & & \\
\hline \multirow{3}{*}{$\begin{array}{l}\text { Satisfaction } \\
\text { status }\end{array}$} & Between groups & 107.236 & 2 & 51.369 & $8.311^{*}$ \\
\hline & Within groups & 1497.096 & 549 & 2.805 & \\
\hline & Total & 1645.259 & 551 & & \\
\hline $\begin{array}{l}\text { Satisfaction with Opportunity for } \\
\text { Academic publication }\end{array}$ & Between groups & 107.236 & 2 & 52.618 & $19.662^{*}$ \\
\hline
\end{tabular}




\begin{tabular}{llllll}
\hline & Within groups & 1497.096 & 549 & 2.727 & \\
& Total & $\mathbf{1 6 0 4 . 3 3 2}$ & $\mathbf{5 5 1}$ & & \\
Satisfaction with Administrators' & Between groups & 111.988 & 2 & 55.994 & $17.508^{*}$ \\
& & & & & \\
Staff relations & Within groups & 1755.822 & 549 & 2.805 & \\
& Total & $\mathbf{1 8 6 7 . 8 1 0}$ & $\mathbf{5 5 1}$ & & \\
\multirow{2}{*}{ Satisfaction with Workload } & Between groups & 1793.117 & 2 & 51.369 & $8.311^{*}$ \\
& Within groups & 11328.109 & 549 & 20.636 & \\
\hline & Total & $\mathbf{1 3 1 2 2 . 1 0 9}$ & $\mathbf{5 5 1}$ & & \\
\hline
\end{tabular}

*Significant at .05 level; critical $\mathbf{F}_{2.549=3.02}$

The result presented in table 1 shows the group means and standard deviations for the three groups of lecturers' job satisfaction. The result presented in table 2 shows the actual result of analysis of variance of the influence of administrators' human resource management effectiveness on the level of lecturers' job satisfaction with work load - 18.31; satisfaction with professional status 27.03; satisfaction with opportunity for academic publication 19.66; satisfaction with administrators' staff relations 17.51; overall lecturers' job satisfaction 43.45 are greater than the critical f-ratio of 3.02 at .05 level of significance with 2 and 549 degrees of freedom. With these results, the null hypothesis is rejected in each of the five instances (subvariables). This means that there is a significant influence of administrators' human resource management effectiveness on the level of lecturers' job satisfaction. The pattern of the influence of administrators human resource management effectiveness on the five subvariables was explored further using the fishers' least significant difference (LSD) multiple comparison analysis at 0.5 level of significance. The results of these analyses are presented in table
3

Table Three: Results of fisher's least significance difference (LSD) multiple comparison analysis of the significance influence of administrators' human resource management on lecturers' job satisfaction

\begin{tabular}{|c|c|c|c|c|}
\hline Sub- variable & Group & $\begin{array}{l}\text { Low } \\
(N=219)\end{array}$ & $\begin{array}{l}\text { average } \\
(\mathrm{N}=186)\end{array}$ & $\begin{array}{l}\text { High } \\
(N=147)\end{array}$ \\
\hline $\begin{array}{l}\text { Satisfaction with } \\
\text { Workload }\end{array}$ & $\begin{array}{l}\text { low } \\
\text { Average } \\
\text { High }\end{array}$ & $\begin{array}{l}15.52^{*} \\
-4.15^{\star c} \\
-585^{*} \\
\text { MSW = } 2.81\end{array}$ & $\begin{array}{l}-0.72^{b} \\
16.54 \\
1.77\end{array}$ & $\begin{array}{l}-1.03 \\
-0.311 .62 \\
16.85\end{array}$ \\
\hline $\begin{array}{l}\text { Satisfaction with } \\
\text { Professional status }\end{array}$ & $\begin{array}{l}\text { low } \\
\text { Average } \\
\text { High }\end{array}$ & $\begin{array}{l}16.11^{\mathrm{a}} \\
-2.29^{\star \mathrm{c}} \\
-5.71^{*} \\
\text { MSW } 2.73\end{array}$ & $\begin{array}{l}-0.50^{b} \\
16.61 \\
-4.47\end{array}$ & $\begin{array}{l}-1.27 \\
-0.31 \\
17.38\end{array}$ \\
\hline $\begin{array}{l}\text { Satisfaction with } \\
\text { Opportunity for } \\
\text { Academic publication }\end{array}$ & $\begin{array}{l}\text { low } \\
\text { Average } \\
\text { High } \\
\text { Total MSW = }\end{array}$ & $\begin{array}{l}16.05^{a} \\
-5.08^{* c} \\
-5.71^{*} \\
2.73\end{array}$ & $\begin{array}{l}-0.87^{b} \\
16.92 \\
-0.70\end{array}$ & $\begin{array}{l}-0.99 \\
-0.12 \\
17.04\end{array}$ \\
\hline $\begin{array}{l}\text { Satisfaction with } \\
\text { Administrators' } \\
\text { Staff Relations }\end{array}$ & $\begin{array}{l}\text { low } \\
\text { Average } \\
\text { High }\end{array}$ & $\begin{array}{c}16.51^{\mathrm{a}} \\
-3.94^{\star \mathrm{c}} \\
-5.80^{*} \\
\mathbf{M S W}=\mathbf{3 . 2 0}\end{array}$ & $\begin{array}{l}-0.73^{\mathrm{b}} \\
17.24 \\
1.93^{*}\end{array}$ & $\begin{array}{l}-1.03 \\
-0.36 \\
17603\end{array}$ \\
\hline
\end{tabular}


Overall lecturers

Job satisfaction low

Average

High

$\mathrm{MSW}=\mathbf{2 0 . 6 4}$ $64.49^{\mathrm{a}}$

$-6.01^{* c}$

$-9.18^{*}$

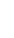

$-2.82^{b}$

4.56

67.32

$-3.27$

4.43

4.65

\begin{abstract}
A $\quad$ - $\quad$ group means are placed along the diagonal
B $\quad$ - $\quad$ Differences between group means are above the diagonal

C - - Fisher's t-values are below the diagonal

* $\quad$ - $\quad$ Significant at .05 level (critical $t=1.96)$
\end{abstract}

\section{DISCUSSION}

The hypothesis sought to find out the influence of administrators' human resource management effectiveness on lecturers' job satisfaction. The influence of this variable on each of the four dimension of lecturers' job satisfaction was tested as well as on the overall (all the four put together). In the case of the influence of administrators' human resources management effectiveness on lecturers' job satisfaction with respect to workload, the findings showed significant Fisher's t-values of -4.15 and 5.85 with the corresponding high mean of 16.85 and average mean score of 16.54 .

Influence on satisfaction with professional status showed significant Fisher's tvalues of -7.32 and -4.47 with corresponding high mean score 17.38 and average mean score of 16.61. Influence on satisfaction with respect to opportunities for academic publications showed significant Fisher's t-values of -5.08 and -5.71 with corresponding high mean score of 17.04 and average mean score of 16.92. Influence on satisfaction with respect to administrators' staff relationship showed significant Fisher's t-values of -3.94 and -5.80 with the corresponding high mean score of 17.60 and average mean score of 17.24. Taken together, the influence of administrators' management of human resources effectiveness on the overall dimension (all the four dimensions put together) of the dependent variable showed significant Fisher's t-values of 9.18 and -3.27 with the corresponding high mean score of 68.87, average mean score of 67.32 and low mean score of 64.49 respectively. These showed that administrators' human resources management effectiveness has a significant influence on lecturers' job satisfaction in tertiary institutions in Cross River and Akwa Ibom States of Nigeria.
These findings are largely supported by the following earlier research findings. In studies conducted by Cooper and Rayne (1980) and Dilworth and Barker (1991), the findings showed that the administrators' abilities to promote professional growth through training opportunities was one of the basis of motivating lecturers for high productivity and enhancing their job satisfaction. Also in the study conducted by Odoegbulem (2003), it was found that administrators' human resources management effectiveness through in-service training, workshops and seminars significantly influenced teachers' (lecturers') job satisfaction and efficiency in educational institutions. It is obvious that for staff management to produce desirable results in job satisfaction the personal egocentric and professional growth needs for personal, recognition and acceptance, respect for the person and dignity of the individual lecturers (staff) should be provided for. The professional growth include creating opportunities for occasional growth - oriented professional training programmes for lecturers, and this should be devoid of all forms of favoritism, and sentiments. Accordingly, in a study conducted by Odoegubulem (2003) on strategies for improving human resource management, the findings showed that lecturers' participation in decisionmaking, organizing workshops and enlightenment programmes for staff increased their feelings of togetherness and comradeship, resulting in their job satisfaction.

\section{CONCLUSION AND RECOMMENDATIONS}

In the light of the discussion above, it was concluded that administrations of tertiary institutions should ensure that lecturers are offered opportunities for re-training to enhance their professional growth, adopt other indices of 
staff motivation for job satisfaction and improved performance.

Based on the findings of the study and the conclusion arising therefrom, it was recommended that:-

1. Administrators of tertiary institutions should ensure that the number of lecturers employed meet the required student-teacher ratio by the National Universities Commission (NUC) for improved performance and job satisfaction.

2. Administrators of tertiary institutions should adequately compensate lecturers carrying excess workload as this affects their job satisfaction.

3. Administrators of tertiary institutions should promote the professional growth of lecturers by recommending them for staff development programmes, conferences and workshops to update their knowledge through interactions with fellow professionals to enhance job satisfaction and improved performance.

4. Lecturers recommended for growthoriented programmes should be devoid of favouration and sentiments.

5. Administrators of tertiary institutions should establish and sustain harmonious relationships with and among lecturers in the departments by respecting and recognizing the worth, dignity and hardwork of the individuals as this would enhance job satisfaction.

\section{REFERENCES}

Aguokoaguo, O. N., 2003. Educational administration and resource management for effective instruction in Nigerian tertiary institutions in The Journal of WCCI Nigeria Chapter, 4, (1): $247-254$.

Adetoro, J. A., 2009. Resource management in Education in Babalola, J. B and Ayeni, A. O. (eds) Educational management: Theories and Tasks Lagos: Macmillan Nigeria Publishers. $599-613$

Akpan, C. P., 2001. School physical facilities maintenance in the $21^{\text {st }}$ century.
International Journal of Educational Administration, planning and Research, 1, (1): $124-130$.

Armstrong, M., 2009. Armstrong's Handbook on Human Resource Management Practice London: Kogan page.

Asiakaka, I. P., 2009. Career Development in Education Management in Babalola, J. B and Ayeni, A. O. (eds) Educational management: Theories and Tasks Lagos: Macmillan Nigeria Publishers. $406-427$.

Babalola, J. B and Ayeni, A. O., (Eds) Educational management: theories and Tasks. Lagos: Macmillan Nigeria publishers 599-613.

Bland, D. E., 1990. Management higher education. Great Britain: Cassel Educational.

Dilworth, M. E and Baker, R. K., 1991. Motivation rewards and incentive. Trends and issues London: Pitman.

Emechebe, S. N., 2009. Human Resource Management in Education in Babalola, $\mathrm{J}$. $B$ and Ayeni, A. O. (eds) Educational management: Theories and Tasks Lagos: Macmillan Nigeria Publishers. $629-645$

Federal Republic of Nigeria., 2004. National policy on education Lagos: Federal ministry of Information.

Human Resource Availability for Environmental literacy and adaptation to climate change Nigeria journal of education administration and planning (NAEAP) 10 , 2. $181-190$.

Ibiam, N., 2011. Resource management in Educational International Journal of Educational Administration Planning and Research 4, 2 82-93

Idih, E. I. N., 1997, September. Human resource management for effective business education. The researcher Journal of 
Nigerian Education Research Reporters Association, 2, (1): $36-42$.

Manpower Resource Planning for Improvement Policy Issues in the Management of secondary School inventions NAEAP 9, $3,23-40$

Mgbekem, S. J. A., 2004. Management of University Education in Nigeria. Calabar: University of Calabar press.

Nnachi, R. O., 2009. Curriculum implementation at the tertiary level of Nigerian Education. Curriculum Theory and Practice (186195). Jos: Curriculum Organization Nigeria

Nsa E. O. E and Issac A., 2007. Quality Control Measures for Sustainable Higher Education in Nigeria. J. B Babalola, G. A. Akpan, A. O. Ayeni \& S.O. Adedeji (eds) Access, Equality and Quality in Higher Education

Odoegbulem, A., 2003, October. Strategies for improving human resources management for effective instruction in secondary school in Owerri educational zone. The Journal of WCCl Nigerian Chapter, 4, (2): 107 - 113.

Ofojebe, W. N., 2009. Manpower Resource Planning for Improvement Policy Issues in the management of Secondary Schools Inventions Nigerian Journal of Education Administration and Planning 9, (3): 23 - 40.

Onuka, A. O. U., 2009. Resource Management in Education in Babalola, J. B and Ayeni, A. O. (eds) Educational management: Theories and Tasks Lagos: Macmillan Nigeria Publishers. 614 - 626

Onukwa, J. O., 1998. Management of business education programmes in institutions of higher learning in Nigerian. Problems and suggestions. Vocational / Technical education and technology growth: NVA publication (121 - 126).
Uche, C. M., 2011. Human Resource Management in Higher Education (eds) Bassey S. U and Bassey U. U. management of Higher Education in Africa. Uyo: Abaam Publishing co. 334367.

Zwalchir, L. A and Buenyen, H. N., 2009. Workload management in the school system Education in Babalola, J. B and Ayeni, A. O. (eds) Educational management: Theories and Tasks Lagos: Macmillan Nigeria Publishers. 833- 838. 